\title{
The economic expansion in the US since 2009 and Donald Trump's ambitions to 'drain the swamp'
}

\author{
Trevor Evans* \\ Institute for International Political Economy, Berlin School of Economics and Law, Germany
}

\begin{abstract}
Since the prolonged recession in 1980-1982 which laid the basis for the emergence of finance-led capitalism in the US there have been four phases of economic expansion. The first three ended with increasingly severe recessions in 1990-1991, 2001 and 2007-2009. The most recent expansion, which began in mid 2009, has been characterised by relatively low growth and investment has been weaker than in previous expansions. Unemployment has fallen sharply, but many of the new jobs have been in low-paid services. The Trump government's much-touted investment programme is dependent on mobilising private funding but this has not yet been very forthcoming. Moves to relax the tighter banking regulations introduced in 2010, while strongly welcomed by the big banks, have been widely criticised. Key indicators of financial tensions are unusually low, but profitability and investment, which usually serve as leading indicators of the business cycle, have begun to decline and this suggests that the current expansion could be approaching an end.
\end{abstract}

Keywords: US economy, profitability, finance, wages, business cycle, crisis

JEL codes: E25, E32, E44, E58, E65, F44, G01

\section{INTRODUCTION}

The current economic situation in the United States can be seen as the result of three factors. The first is the long-term shift to a neoliberal order. The key development here was the Monetarist offensive launched by the Federal Reserve between late 1979 and late 1982, and the policies of deregulation introduced by the Reagan government, which took office at the start of 1981, and deepened by subsequent governments, in particular the Clinton government in the 1990s.

The second factor is the US business cycle. Periods of economic expansion in the 1980s, the 1990s and the early 2000s were each brought to an end by increasingly severe crises, the most recent of which, in 2007-2009, came perilously close to causing a collapse of the US - and hence the international - financial system. ${ }^{1}$ The most recent expansion, which began in mid 2009, has been unusually weak, and is already relatively long by comparison with other recent expansions.

The third factor is the presidency of Donald Trump which began in January 2017. Despite a populist rhetoric and the dependence of his electoral victory on mobilising

* Many thanks to Dorothea Schmidt for numerous helpful comments and suggestions.

1. For details of the expansion in the early 2000s and subsequent crisis, see Evans (2009).

Received 31 January 2018, accepted 19 February 2018 


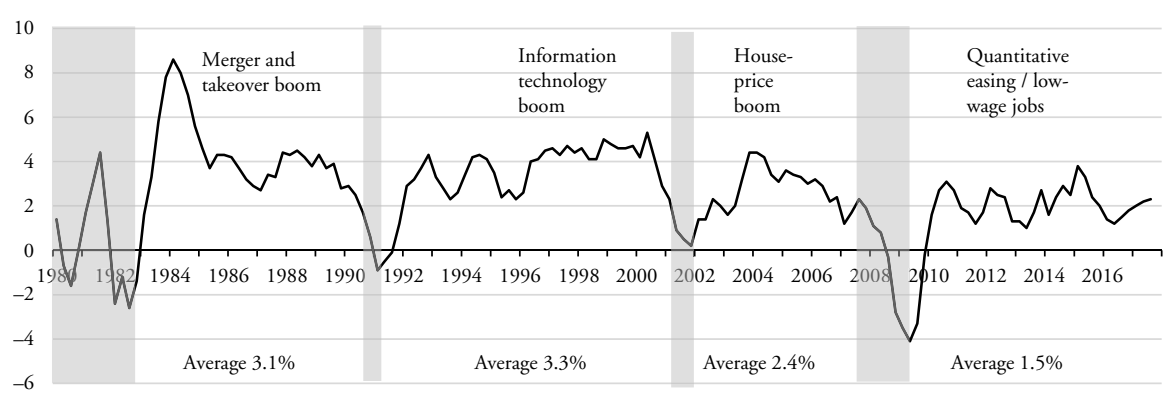

Notes: Shaded areas show NBER designated recessions. Figures show peak-to-peak average annual growth.

Source: BEA (2017a: table 1.1.11).

Figure 1 Growth of US real GDP over four quarters (per cent)

white working-class support, in government he has pursued an unashamed series of measures which primarily benefit the very wealthiest sectors of US society.

\section{DRAINING THE SWAMP}

Donald Trump campaigned for the US presidency as a Republican, claiming to be an outsider who was uncorrupted by Washington ways and promising that, once elected, he would 'drain the swamp' of its corrupt practices. His electoral success in November 2016 was due to unexpected victories in swing states with large working-class populations. Trump's campaign played incessantly to blue-collar workers' insecurities about employment and stagnant wages, promising to bring jobs back to the US and attacking what he called bad trade deals. According to a detailed study of the US new right by David Neiwert (2017), racial and ethnic shifts also played a key role in securing Trump's victory. Neiwert cites an in-depth investigation conducted by The Wall Street Journal in the months before the election which found that Trump won the Republican presidential primaries in areas where there had been a significant inflow of Latino residents to predominantly white districts and that this carried over into the results of the election itself. Trump, he notes, won among white voters in nearly every demographic category in most of the Midwestern states, obtaining a narrow majority in the key states of Pennsylvania, Michigan and Wisconsin.

The focus of Trump's campaign in the run-up to the election was masterminded by Stephen Bannon, chairman of the alt-right Breitbart News. Bannon is credited with being the architect of Trump's 'America First' strategy and, on taking office, Trump appointed Bannon chief strategist at the White House. Following several reportedly chaotic months, retired general John Kelly was appointed as chief of staff to bring some order into the workings of the White House. In August, after a car was driven into opponents of a white supremacist demonstration in Charlottesville, Virginia, killing one person and injuring many more, Bannon was widely condemned for advising Trump to express criticism of both sides, and Kelly seized the opportunity to convince Trump that Bannon should leave the White House.

The failure of Trump to roundly condemn the racist violence also prompted a highprofile response from a number of senior business men and women. Twelve chief 
executives who had been appointed to Trump's prestigious Strategic and Policy Forum held a phone conference and agreed that the organisation should be disbanded. Meanwhile, several members of another advisory council, the Manufacturing Jobs Initiative, had decided to resign in protest at Trump's behaviour. However, after Trump was informed of the two groups' decisions, he pre-empted their announcements by issuing a statement that he had decided to disband the two bodies (The New York Times 2017b).

During the election campaign, Trump had been particularly vociferous in attacking Wall Street but on taking office he appointed two former executives from Wall Street's premier bank, Goldman Sachs, to key financial jobs: Gary Cohn, former deputy to Goldman chief Lloyd Blankfein, was made head of the National Economic Council, while Steven Mnuchin, once Goldman's chief information officer, became Treasury Secretary. Nevertheless, at the end of the first year in office, an unprecedented number of key government positions remained unfilled, in part because of Trump's insistence on selecting candidates who demonstrate unquestioned personal loyalty.

The Trump government's first major legislative initiative attempted to revise the Obama government's signature achievement, the Affordable Care Act (Financial Times $2017 b$ ). Obama, in a - forlorn - attempt to gain Republican support, had actually adopted the free-market health-care proposals developed by the right-wing Heritage Foundation. The new Republican proposals would have abolished Obama's 'individual mandate', which required all citizens to purchase health insurance, and without which premiums would rise as the young and healthy forwent insurance. However, after two attempts, in July and September 2017, Trump was obliged to abandon his initiative (The New York Times 2017c). With only a narrow majority in the Senate, he could not obtain the support of senators on the right of the party, who thought the revisions did not go far enough, and from others on the more liberal wing, who wished to protect their constituents from a loss of the Obama health-care provisions. Unable to obtain a majority in Congress, in October Trump issued an executive order which would allow small businesses and their employees to obtain health insurance outside the provisions of the Obama law (Financial Times 2017f). By providing cheaper options for healthier people, the measure threatened to undermine the economics of the broader programme.

\section{A TAX POLICY FOR THE RICH}

The 2007-2009 recession led to a major increase in the government deficit, which rose from 2 to 10 per cent of GDP. Spending increased as a result of rescuing the banks and rising welfare outlays, while tax revenues fell. In addition, on taking office in early 2009 , the Obama government immediately introduced a major recovery programme involving both increased spending and tax cuts, eventually worth $\$ 830$ billion (Blinder 2013: 227-235). Despite the weakness of the economic recovery, the deficit began to decline in 2010 and since 2015 it has stabilised at around 4.5 per cent of GDP. Without a majority in Congress, the Obama government was unable to undertake any further expansionary policies and this fell to the Federal Reserve, which followed an exceptionally expansionary monetary policy.

At the outset of the crisis, the Federal Reserve reduced the official target for its lead interest rate to $0-0.25$ per cent - in practice zero - and it maintained this right through until late 2015. Since then, it has begun to raise the lead rate cautiously, in small steps, and following a further small rise in December 2017, the target range stood at 1.25-1.5 per cent. At the height of the crisis the Fed also launched a massive programme to increase the supply of reserves to the banking system. In three phases of what is euphemistically 
entitled 'quantitative easing', the Fed pumped money into the banking system, increasing the supply of reserves from around $\$ 750$ billion (5 per cent of GDP) to almost $\$ 4.2$ trillion (23 per cent). The Fed claims this has helped to reduce long-term interest rates, and so to provide support for investment. By driving up asset values it has certainly provided a windfall for the rich, although the policy has been criticised as ineffective and even dangerous by more conservative economists (see, for example, Taylor 2017).

During the election campaign, Trump repeatedly advocated a $\$ 1$ trillion investment programme aimed at revitalising the US's ailing infrastructure, such as roads, waterways and bridges, much of which dates from the 1930s and the initial postwar years (The New York Times 2017a). After taking office he talked of a public-private partnership, where $\$ 200$ billion from the government would help to mobilise a further $\$ 800$ billion of private investment over 10 years. In the summer of 2017, Trump's spokesperson said that a plan would be forthcoming in the late summer or early autumn and there was even talk of combining such a programme with tax reform. In the event, however, no major announcement on infrastructure investment was forthcoming. ${ }^{2}$

Following almost a whole year without any major legislative successes, in December 2017 Republicans in both houses of Congress managed to agree on a major - if highly controversial - programme of tax reductions (The New York Times 2017g). Congressional rules required that, since the Republicans could only count on a simple majority for their proposals, the impact of the tax cuts had to be limited to $\$ 1.5$ trillion over ten years and, consequently, the cuts in personal taxation will automatically expire in 2025 .

Trump had initially proposed that the tax on business profits should be reduced from 35 per cent to 20 per cent, although in the final proposal the figure of 21 per cent was adopted in order to keep within the long-term limit. For multinationals, there will be a shift from worldwide taxation, which is only levied if profits are actually repatriated to the US, to a system of national taxation, with a special low rate to encourage a one-off repatriation of profits which have been accumulated abroad by companies like Apple, Cisco and Microsoft. There will also be a pass-through rate for personal businesses which were previously taxed at the highest personal rate of taxation so that they too will gain a similar benefit to the 21 per cent tax on profits.

The top personal rate of taxation was reduced from 39 per cent to 37 per cent, although the income at which this applies was raised slightly, to $\$ 500000$. Smaller reductions are to be introduced for lower income bands. The personal tax-free allowance was raised to $\$ 12000$, but a wide range of other allowances were eliminated. Nevertheless, mortgage interest deductions continue to be allowed, albeit with the maximum amount eligible for relief reduced from $\$ 1$ million to $\$ 750000$. Original intentions to scrap allowing local taxes to be deducted from federal income tax payments - a move intended to squeeze Democratic states with higher spending - were replaced by imposing a limit of $\$ 10000$ on what might be counted, a concession to Californian Republicans. The Trump government also took advantage of the tax bill to include provisions to end the Affordable Care Acts requirement that made health insurance obligatory and to open the Arctic National Wildlife Refuge in Alaska to energy explorations.

Treasury Secretary Mnuchin claims that the tax reductions will result in US economic growth rising by 0.7 per cent a year. However, this is widely questioned. According to

2. In February 2018, the White House (2018) finally published an investment plan in which public investment of $\$ 200$ billion is supposed to mobilise a total of $\$ 1.5$ trillion of investment. The proposal has been widely criticised as only projects which private investors find attractive will be financed. There is also scepticism about the amounts which will be forthcoming from private investors (The New York Times 2018). 
estimates by Congress's own non-partisan Committee on Taxation, the tax cuts would raise output by 0.8 per cent over ten years, or 0.08 per cent a year (Joint Committee on Taxation 2017). The renowned mainstream Penn Wharton Budget Model at the University of Pennsylvania estimated the increased output over ten years would be between 0.5 and 1.0 per cent (Penn Wharton Budget Model 2017).

Trump's tax plans have been extensively pilloried by his mainstream opponents. A New York Times editorial characterised the goal of the Republican tax plans as being 'to enrich the country's elite at the expense of everybody else' and referred to the proposals as a 'looting of the public purse by corporations and the wealthy' (The New York Times 2017e). In a more salutary analysis, the paper warned that the drastic decline in state revenues would provide the Republicans with a justification for moving against entitlement programmes: 'Republicans are preparing to use the swelling deficits made worse by the package as a rationale to pursue their long-held vision: undoing the entitlements of the New Deal and Great Society, leaving government leaner and the safety net skimpier for millions of Americans' (The New York Times 2017f).

\section{RISING PROFITABILITY AND WEAK INVESTMENT}

Since the 1990s, profitability has risen to new heights in each business-cycle expansion, as shown in Figure 2. The share of non-financial corporations' profits in national income fell sharply during the 2007-2009 recession, but it then rose again to reach a peak in 2014 that was even higher than at the previous cyclical peaks in 1998 and 2006. Since 2015, however, profitability has begun to decline and, based on the experience of previous cycles, this could be an early indicator that the current economic expansion is drawing to an end.

Estimates for the rate of return on capital invested show a very similar pattern to that of the share of profit. $^{3}$ Significantly, a recent study shows that the rate of return obtained by the very largest companies is considerably higher than that of other companies: companies with assets of over $\$ 1$ billion achieved an average return of 13.5 per cent in recent years while those with assets between $\$ 250$ million and $\$ 1$ billion averaged around 9.5 per cent

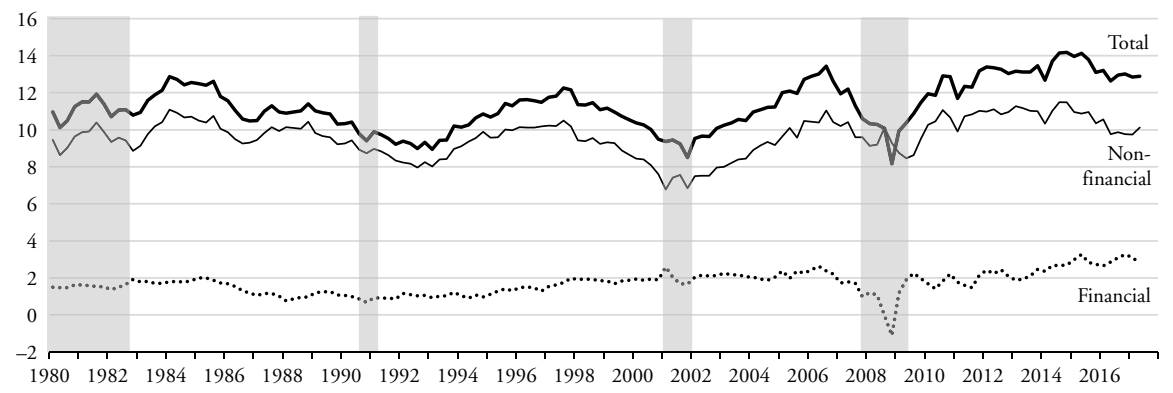

Note: Shaded areas show NBER designated recessions.

Source: BEA (2017a: table 1.14).

Figure 2 US corporations' profits (percentage of national income)

3. See, for example, Bivens (2017: 10, fig. G). Roberts (2016: 22, fig. 1.4) shows the peak in the rate of profit in 2014 as slightly lower than that in 2007. 
(McKinsey Global Institute 2017: 26). The profitability of larger US companies has benefited greatly from the outsourcing of important stages of the production process to subsidiaries or unaffiliated companies in lower-waged developing countries, which have been estimated to involve cost savings of up to 60 per cent (Milberg/Winkler 2013: 105-111). ${ }^{4}$ Furthermore, research by Gérard Duménil and Dominique Lévy implies that the official figures seriously under-measure what might reasonably be considered as profits. They point out that, between the 1980s and 2009, when they concluded their research, the share of national income going to the top 5 per cent of earners in the corporate sector - mainly top managers effectively appropriating a part of the surplus - had risen by some 10.8 per cent of national income (Duménil/Lévy 2013: 50).

In contrast to profitability, fixed investment has tended to decline. Since the 1990s the upturn of investment has been weaker in each successive business cycle and the most recent wave has been the weakest of all, with little increase since 2014 (see Figure 3). US corporations have been investing in their subsidiaries in other countries and, even within the US, investment in important forms of equipment such as industrial robots has risen, particularly in the motor industry, ${ }^{5}$ but fixed investment in the economy as a whole has been unusually weak. ${ }^{6}$ According to a McKinsey study, US manufacturers have deferred investment and focused on cutting costs and, as a result, the average age of factories has increased from 16 years in 1980 to 25 years in 2017 (McKinsey Global Institute 2017).

The lack of investment in fixed capital is associated with a particularly striking feature of the most recent expansion, the unprecedentedly low growth of labour productivity. It is not unusual for labour productivity to fall at the onset of a recession, when output falls faster than firms lay off workers. But once output begins to recover, with a slimmer labour

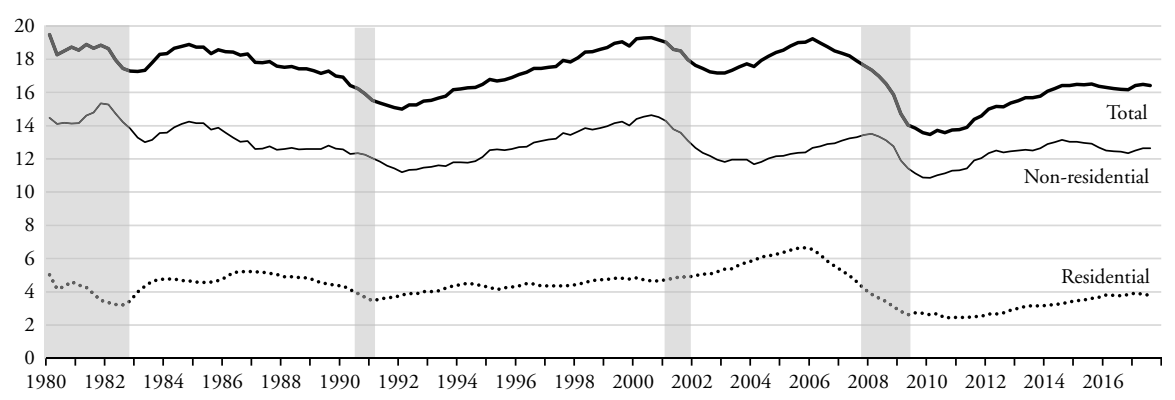

Note: Shaded areas show NBER designated recessions.

Source: BEA (2017a: table 1.1.5).

Figure 3 US fixed investment (percentage of GDP)

4. The benefits which accrue to developed countries from imports generated as part of global value chains in low-wage economies are also stressed by Smith (2016).

5. The US employs the third-largest number of industrial robots after China and South Korea. According to the International Federation of Robotics (2017), the number of industrial robots in use in the US increased from 14000 in 2010 to 31000 in 2016.

6. For a detailed mainstream analysis of the possible explanations for the slowdown in investment, see Gutiérrezy/Philipponz (2017). They identify decreased competition - associated with the dominance of a small number of giant firms in key sectors - and increased short-termism as the main causes of the slowdown. 
force, productivity has in the past risen strongly. In previous expansions labour productivity increased at a rate of 2 to 3 per cent a year but from 2011 to 2017 labour productivity grew at only 0.5 per cent a year (The Conference Board 2017).

According the progressive Economic Policy Institute (EPI), the decline in the growth of labour productivity is primarily due to the weakness of private investment which, in turn, is a response to the 'capital overhang' that has left firms with excess capacity as a result of the depth of the recession and the slow pace of the subsequent recovery (Bivens 2017). For the EPI, the answer is to promote higher growth through expansive government policies. A rather similar analysis of the problem is put forward by four wellknown conservative economists - except that, in their view, the solution is to cut back the role of the state and reduce the web of regulations which, according to them, is responsible for holding back entrepreneurial enthusiasm (Cogan et al. 2017). But an altogether more sobering view has been advanced recently by Robert Gordon in a magisterial study of the development of the US economy since the Civil War. Gordon (2016) argues that between 1870 and 1970 the US economy was utterly transformed by the introduction of a number of path-breaking - and unrepeatable - technological innovations, including electricity, motor vehicles and airplanes, which completely changed everyday life in the country. He identifies a further period of rising productivity between 1996 and 2004 associated with the impact of computers and communication technology, but he argues that its effect was limited compared with the earlier phase which, in his words, 'changed everything'. While Gordon does note that major US companies hold a dominant international position, his analysis points to the US economy entering a fundamentally slower period of growth.

Despite the relatively weak upturn in fixed investment since the crisis, corporate borrowing has risen considerably. Non-financial corporations' debt increased steadily in the years leading up to the crisis, and by 2008 was equal to a record 45 per cent of GDP. Companies cut their borrowing sharply in response to the crisis, but since 2011 borrowing has increased again and by 2016 debt once again stood at 45 per cent of GDP (Federal Reserve Board 2017: table D3, series LA104104005).

Debt has risen so much because, despite high profits and relatively weak fixed investment, companies have been borrowing to finance unprecedented payouts to their shareholders. Dividend payments to shareholders have risen steadily, from around 1.5 per cent of GDP in the early 1980s to some 3.5 per cent during the most recent expansion (see Figure 4). This reflects the increasing influence of institutional investors but also the interests of corporate executives, who are awarded large blocks of shares as part of their compensation packages. In addition, a significant legal change in 1980 permitted companies to buy back their own shares - something which until then had been regarded as illicit price manipulation (Lazonick 2015). This has allowed companies to distribute rising amounts to shareholders through share buy-backs, something which is subject to lower taxation than dividend payments, and which has the added attraction of pushing up the value of the outstanding shares. In the last few years share buy-backs have amounted to about 3 per cent of GDP - almost as much as dividend payments - so that the total distributed to shareholders each year from 2011 to 2017 has been equal to around 6 per cent of GDP. For comparison, this is equal to around two-thirds of the amount which the companies have allocated to fixed investment.

The scale of the share buy-backs, together with the Fed's highly expansive monetary policy, has contributed to a steady rise in stock-market values. Stock prices fell sharply during the 2007-2009 recession but by 2010 the Shiller Price-Earnings Index (2018) had returned to its long-run average value of 20 . Share prices then rose steadily and, strengthened by Trump's election victory and the expected programme of tax cuts, by 


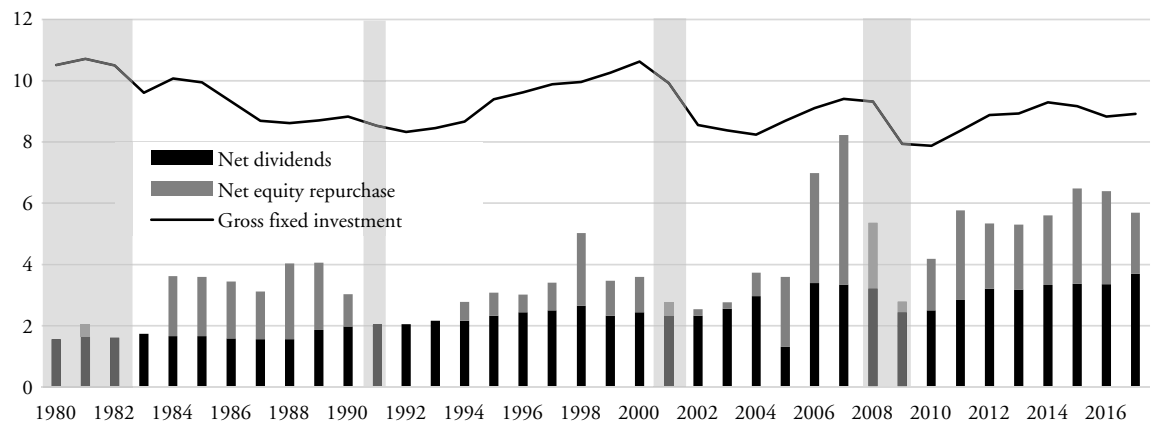

Note: Shaded areas show NBER designated recessions.

Source: Federal Reserve Board (2017: table F 103). 2017 figures based on first three quarters.

Figure 4 US non-financial corporations' dividends and equity repurchases (percentage of GDP)

December 2017 the Shiller index had risen to 32.4, an increase of 64 per cent since 2010 and of 16.4 per cent since Trump was elected. Some commentators had already begun to warn that US stocks were significantly over-priced - and hence at risk of an 'adjustment' (see, for example, Financial Times 2017c).

Companies with relatively high tax rates, and with revenues mainly in the US, will gain most from the Trump government's reduction in corporate taxation (Financial Times 2017i). Oil refiners, railways, airlines and banks are expected to be among the biggest beneficiaries. Delta Airlines announced that it expected that it would be able to raise its dividend payments by 18 to 19 per cent. Warren Buffett's investment fund, Berkshire Hathaway, which invests primarily in the US, is forecast to gain about $\$ 2.6$ billion, a rise of 15 per cent. AT\&T, Boeing and Comcast were among companies which announced plans to raise investment or wages as a result of the tax cuts, while Boeing and Pfitzer announced plans to use part of their windfall to increase their share buy-back programmes (Financial Times 2017j).

\section{RELAXING FINANCIAL REGULATION}

Since the 1990s a small number of the very biggest banks have steadily strengthened their dominant position in the US. This was accelerated by the Clinton government's abolition in 1999 of the Depression-era law enforcing a legal separation between investment and commercial banking and which has led to the emergence of giant financial holding companies. Following a relentless process of mergers and takeovers, the biggest five banks increased their share of banking assets from 17 per cent in the early 1990 s to 52 per cent by 2009 (Federal Reserve Bank of New York 2017: 35). In the run-up to the crisis these big banks played a central role in packaging risky mortgages in highly complex securities, whose collapse played a key role in detonating the 2007-2008 crisis. By 2017 the big banks had been obliged to pay a total of $\$ 150.1$ billion in fines for their part in the dubious financial engineering which led up to the crisis. Bank of America alone had to pay $\$ 56$ billion while JPMorgan was hit for a total of $\$ 27$ billion (Financial Times 2017a). But, as Jesse Eisinger (2017) points out in his meticulous dissection of the justice department's prosecutions, not one senior banker was obliged to spend time behind bars. 
US banks have been subjected to two major sets of regulatory changes since the crisis, the Dodd-Frank Wall Street and Consumer Protection Act of 2010, and the Basel III international banking regulations agreed in 2010-2011. The Dodd-Frank Act is extraordinarily long and complex. Even then, it only sets out principles which had to be converted into rules that could be implemented by the supervisory authorities, and there was massive pressure from the banks for exemptions. One of the Act's major innovations was the establishment of the Financial Stability Oversight Council, chaired by the Treasury Secretary, which is responsible for monitoring and identifying the build-up of excessive risk in the US financial system. The Act also required banks to introduce a 'ring fence' which would isolate riskier investment banking activities so that any losses would not have an impact on commercial banking activities. The former Fed chairman Paul Volcker had, famously, pushed for reintroducing a clear separation between investment and commercial banking activities. In the event, the actual proposals were much weaker as the banks successfully convinced the authorities that some trading was necessary in order for banks to provide commercial banking facilities for their customers. ${ }^{7}$

The international standards on how much capital banks should hold, first agreed under the auspices of the Basel-based Bank for International Settlements in 1988 and modified in proposals published in 2004, known as Basel II and still being implemented at the time of the crisis, were revised again in 2010 in the aftermath of the crisis. The most recent standards, known as Basel III, introduced higher capital requirements for banks and also introduced stricter rules on what could be counted as capital. ${ }^{8}$ Controversially, as in Basel II, big banks continue to use their own computer models to assess the riskweighted amount of capital they are required to hold. The new rules also require the very largest 'global systemically important banks' (G-SIBs) to hold additional reserves set at between 1 and 3.5 per cent of assets, to be phased in between January 2014 and January 2018. ${ }^{9}$ In addition to minimum capital requirements, the new Basel agreement set out rules for liquidity coverage ratios (holdings of high-quality liquid assets sufficient to cover net outflows over a 30-day period), and here the US authorities actually chose to impose a higher requirement than the international standard. As with the Dodd-Frank Act provisions, the new Basel rules have been criticised for their complexity and, despite the slight increase, the continuing low level of capital requirements. ${ }^{10}$ Perhaps most strikingly, a recent research paper by the Federal Reserve itself also concluded: 'If the purpose of these capital surcharges is to ensure the survival of G-SIBs through serious crises without extraordinary public assistance, our best estimate suggests that Basel capital surcharges are too low' (Passmore/von Hafften 2017).

Despite Trump's blistering attacks on banks during the election campaign, his government quickly set about preparing proposals to loosen the provisions introduced by the

7. In 2014 the banks successfully lobbied to get the deadline for banks holding private equity fund and hedge fund investments pushed back to 2017. See Foroohar (2016: 288-291).

8. The so-called Tier 1 capital requirement was raised from a risk-weighted 2 per cent of assets to 4 per cent plus an additional 2.5 per cent buffer. See Federal Reserve Board (2014).

9. According to the latest list published by the Financial Stability Board (2017), no bank is required to hold the maximum additional capital of 3.5 per cent of assets, while JPMorgan alone is required to hold an additional 2.5 per cent. Of US banks, Bank of America and Citigroup are required to hold an additional 2 per cent; Goldman Sachs and Wells Fargo an additional 1.5 per cent; and Bank of New York Mellon, Morgan Stanley and State Street an additional 1 per cent of capital.

10. See, for example, the widely cited study by Adamati/Hellwig (2014), which advocates capital requirements of 20 to 30 per cent of assets. 
Dodd-Frank Act. In June 2017, Trump's Treasury Secretary published proposals for revising the regulation of the banking sector, some of which would require legal changes but many of which could be introduced without Congressional approval (US Department of the Treasury 2017). According to the introduction to the report, 'Dodd-Frank created a new set of obstacles to the recovery by imposing a series of costly regulatory requirements on banks and credit unions'. The proposals which followed were very detailed but many involved loosening regulations, in particular for smaller banks. They argued that the threshold for the size of banks which would be subjected to regular stress tests should be raised from $\$ 10$ billion to $\$ 50$ billion of assets, with the flexibility also to exclude those with assets of over $\$ 50$ billion. It proposed that the liquidity coverage ratio, introduced for the first time by the 2010 Act, should only apply to internationally active banks. Banks with assets of $\$ 10$ billion or less would be exempt from the Volcker Rule, which required banks to 'ring fence' their investment banking activities, and rules on proprietary trading should not apply to banks with assets of more than $\$ 10$ billion ... unless they exceed a threshold amount (which was not specified). The report also proposed that the definition of proprietary trading should be simplified, and that banks should be able to hedge risks more easily - that is, engage in the more speculative trading which the Dodd-Frank Act had attempted to limit. More generally the report advocated changing compliance programme requirements, such as the provision of regular detailed information on activities, so as to reduce the regulatory burden.

The Treasury report also proposed that the Consumer Financial Protection Bureau (CFPB), deliberately set up by the Dodd-Frank Act with considerable independence, should be brought under the direct control of the Treasury. According to the report, ' $\mathrm{t}$ ] he CFPB was created to pursue an important mission, but its unaccountable structure and unduly broad regulatory powers have led to predictable regulatory abuses and excesses' (US Department of the Treasury 2017: 13). In fact, this financial watchdog has diligently pursued the interests of consumers and was greatly despised by banks, having obtained $\$ 12$ billion in refunds and cancelled debts for 29 million consumers. In December 2017, when the CFPB's longstanding director retired, a conflict developed over who should fill the post until a new director was appointed: the deputy director (as favoured by the departing director and, apparently, also foreseen by the Bureau's statutes) or an appointee of the Treasury. In the event, the Treasury successfully inserted Mick Mulvaney, Trump's budget director, and a long-standing critic of the CFPB's supposedly excessive reach. Mulvaney immediately proceeded to cancel a significant ongoing action against Nationwide Biweekly Administration, which had been ordered to pay nearly $\$ 8$ million in penalties for misleading mortgage owners. He also stopped approval of payments for some financial crimes and ordered a review of active investigations and lawsuits (The New York Times 2017d).

In November 2017 it was announced that the chair of the Federal Reserve Board, Janet Yellen, who had been appointed by Obama, would not be asked to serve a second term, as has been common in recent times. Trump apparently considered appointing a more radical, right-wing economist, such as John Taylor, who in a famous article had advocated what became known as the Taylor rule, a non-discretionary formula for determining the appropriate growth of reserves to the banking system. In the event, it appears that Trump was advised of the extreme sensitivity of financial markets to his choice, and he proposed to appoint Jaz Powell, an existing member of the Fed's Board of Governors, although one without the academic background of Yellen or her predecessor. At the Congressional confirmation hearing, Powell pleased Republican supporters by saying he was 'supportive' of the idea of rewriting the Volcker rule banning banks' proprietary trading (Financial Times 2017g). 
During the years prior to the crisis, US banks were exceptionally profitable, obtaining a return on equity of around 14.5 per cent with the very biggest banks obtaining a return of over 16 per cent. However, this plummeted in the second half of 2007 and in 2008 the banks registered huge losses, rising to some 20 per cent of their equity in the final quarter of the year. Since 2010 banks have once again begun to generate substantial profits although, due to the higher amounts of capital they are required to hold, the rate of return has averaged around 7.5 per cent, considerably below the rate before the crisis, with the small banks actually achieving a slightly higher return than the biggest banks (Federal Reserve Bank of New York 2017: 12).

In the aftermath of the crisis, banks - and in particular the big banks - were focused on rebuilding their capital, and there was little increase in lending. Bank lending only began to increase again from around 2012, principally due to smaller banks, and it was not until 2015 that lending by the biggest banks began to rise again. Since 2015 bank lending has been increasing at an annual rate of some 5 per cent, around half the rate before the crisis. In 2017, some 50 per cent of lending was for housing, with a further 18 per cent for consumer credit, leaving just 32 per cent for other activities (Federal Reserve Board 2017: table L110). Despite the banks' strengthened capital base, the Office of Financial Research - set up to provide analysis for the new Financial Stability Oversight Council - has expressed concern that the potential impact of a large bank failure remains substantial, and that, among large banks, low interest rates have encouraged risk-taking because investors make increasingly risky investments in order to obtain higher returns (Office of Financial Research 2016: 13).

While the banking system has faced significant regulatory change, the 'shadow banking system' has remained virtually untouched. The shadow banking system consists of a series of financial institutions which, between them, fulfil the function of credit intermediation but, because they are not registered as banks, are not required to comply with the minimum capital requirements which apply to banks. ${ }^{11}$ Shadow banks expanded very rapidly between the mid 1990s and 2008 but then collapsed by some 30 per cent between 2009 and 2012, as shown in Figure 5. The irony is that many of these institutions are actually owned by bank holding companies! ${ }^{12}$ In this way, banks adapted and remained central players in the provision of credit to non-financial companies. They are able to offer cheaper credit during booms but, without a capital buffer, they are much more vulnerable when the economy turns down.

The Federal Reserve is not required to provide support to shadow banking institutions in the event of a crisis, as it is with banks. Nevertheless, because many shadow banking institutions would have collapsed in 2008, and so deepened the crisis yet further, the Federal Reserve established a series of new lending facilities designed to rescue the institutions in each stage of the shadow banking system. ${ }^{13}$ Most of the programmes were launched in the course of 2008 and ran until 2010. According to detailed figures published by the Office for Financial Research in 2016, the shadow banking system provided 38 per cent

11. For a detailed account of the structure of the US shadow banking system, see Pozsar et al. (2013), in which the stages in the shadow credit intermediation process are summarised in table 2. The Office of Financial Research has a broader definition of the shadow banking system and shows it to be slightly larger than the official banking system in 2016. See Office of Financial Research (2016: 29-30).

12. For details of the number of banks and nonbank institutions owned by the ten largest US bank holding companies in 2010, see Cetorelli et al. (2014: 103). Bank of America, for example, owned 117 banks and 176 nonbank institutions.

13. For details of the seven programmes set up by the Federal Reserve, see Poszar et al. (2012: 22-24). 


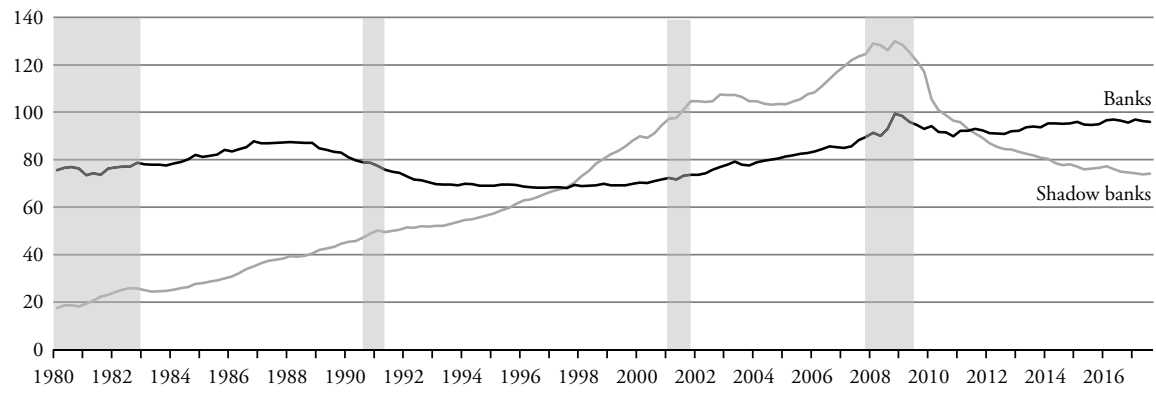

Note: Shaded areas show NBER designated recessions.

Source: Federal Reserve Board (2017: tables L110 and L121-L130), following Poszar et al. (2010). 2017 figure up to Q3.

Figure 5 US bank and shadow bank assets (percentage of GDP)

of US business and household credit compared with 32 per cent by the banking system. ${ }^{14}$ However, the Federal Reserve continues to be concerned that no effective measures have been introduced to regulate the shadow banking system. Speaking at the Institute of International Finance annual members' meeting in 2016, the vice-chair of the Federal Reserve, Stanley Fisher, said in the reserved language of a central banker, 'I worry a little bit about the fact that we in the United States do not have very good mechanisms for dealing with the nonbank sector, the shadow banking system' (The Wall Street Journal 2016.)

The main way in which non-financial companies in the US raise external finance is through issuing bonds. The stock of outstanding corporate bonds increased steadily between the early 1980s and 2003, rising from 12 to 24 per cent of GDP, although there was then a slight decline during the 2002-2007 expansion. Since the most recent recovery began, bond issues have risen strongly, and by 2017 the outstanding value of corporate bonds had reached an all-time high equal to 27 per cent of GDP. The reason for this large increase in borrowing, despite the relatively weak corporate investment, is the need to finance the ever-increasing payouts to shareholders through dividends and share buy-backs.

The Trump government's reduction in the corporate tax rate to 21 per cent is expected to provide large gains for many banks. According to one estimate, Wells Fargo is expected to boost its earnings per share by 17 per cent in 2018, Bank of America by 14 per cent, JPMorgan by 12 per cent and Citigroup by 8 per cent (Financial Times 2017k). However, financial institutions which have been writing off huge losses against their tax obligations are set to lose out by some $\$ 50$ billion from the reduction in tax rates. Citigroup is estimated to be liable for losses of $\$ 16$ billion, AIG for $\$ 6.5$ billion and Bank of America for $\$ 3$ billion (Financial Times 2017j). Nevertheless, a special tax privilege known as carried interest that benefits hedge and private equity funds which Trump had repeatedly said would be eliminated was kept with minor changes. According to Gary Cohen, director of the National Economic Council, '[w]e would have cut carried interest. We probably

14. See Office of Financial Research (2016: fig. 21). The figures for the size of the shadow banking system employed by the Office of Financial Research are slightly larger than those in the Federal Reserve research papers cited above. 
tried 25 times. The reality is that constituency has a very large presence in the House and the Senate' (Financial Times (2017l).

\section{COMBATTING 'UNFAIR' TRADE COMPETITION}

Prior to the crisis, the US had run an ever-increasing trade deficit, which reached an unprecedented 6 per cent of GDP in 2007. The deficit fell sharply during the recession as imports declined, and since 2009 it has steadied to around 2.5 per cent of GDP. For many years, the deficit was financed principally by large inflows of foreign financial capital, in particular official government reserves which were invested primarily in US government securities; since the crisis, there has been a shift towards private bonds, which generate slightly higher yields (BEA 2017b: tables 1.1 and 7.1).

Trump had promised during his election campaign to end what he described as the unfair trade relations to which the US was subject and he committed himself to reducing the country's trade imbalance, which he presents as the main cause of the loss of manufacturing jobs in the US. One of his earliest presidential initiatives, on 20 January 2017, was to announce that the US would withdraw from the Trans Pacific Partnership, a major trade and investment initiative involving 12 countries around the Pacific basin - but which excluded China. In fact, the Obama government had in its final days launched an investigation at the World Trade Organisation (WTO) into Chinese aluminium imports but, apparently, the Trump government has not followed up on this. According to Trump, the WTO has not treated the US fairly and, since the admission of China, is responsible for the huge increase in Chinese imports to the US (Financial Times 2017h). In April 2017, the Trump government launched a 'Section 232' investigation into steel imports from China, but this became bogged down, in part because of opposition from car-makers and other importers of steel, and actually led to a rise in steel imports as users attempted to build up stocks before the imposition of any taxes (Financial Times 2017e).

Trump has also repeatedly attacked the North American Free Trade Agreement (NAFTA), which came into force between the US, Canada and Mexico in 1994, and he sees the US's large trade deficit with Mexico as a major cause of the loss of manufacturing jobs in the US. In September 2017 the Commerce Department, as it prepared to renegotiate the terms of NAFTA, published a report showing that since 1995 fewer of the components and raw materials of goods traded under NAFTA have been made in the United States (Flatness/Rasmussen 2017). A key aim of the negotiations is to reduce Mexico's $\$ 65$ billion annual trade surplus with the US. The Commerce Department is also intending to reopen a trade agreement from 2012 with South Korea, with which the US also has a large trade deficit. Any attempt to reduce imports will, however, be complicated by the fact that some 50 per cent of US trade is linked to materials and semi-finished products which are part of US companies' global supply chains (Financial Times 2017e).

\section{RISING EMPLOYMENT BUT LOW WAGE GROWTH}

Since the beginning of the current economic expansion, the official rate of unemployment has fallen quite strongly (see Figure 6). For men it fell from 10 per cent in 2010 to 4 per cent in 2017, while for women, who were not quite as badly hit by the collapse of manufacturing jobs during the recession, it fell from 8 per cent to 4 per cent. However, the employment situation is not quite as rosy as this might suggest. The figure for the rate of unemployed plus those who would like to work full time but can only find a part-time job 


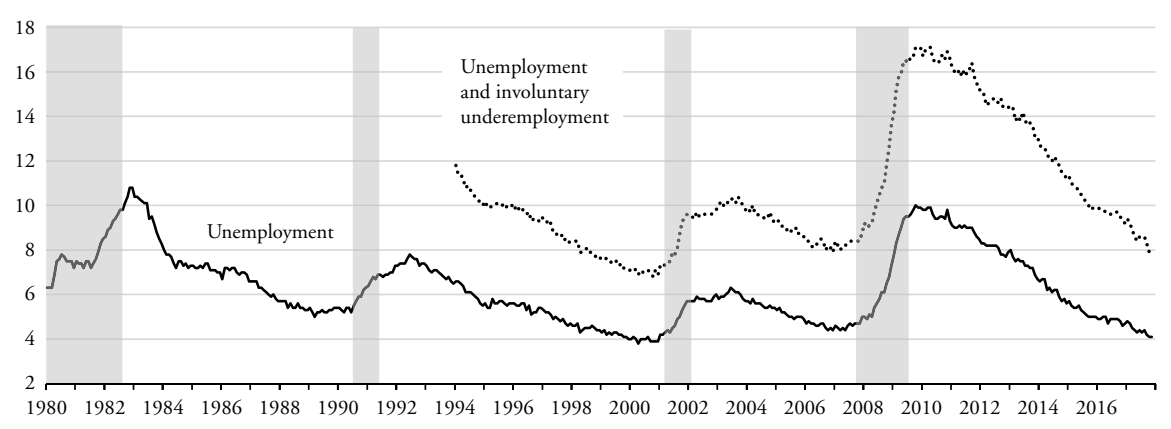

Note: Shaded areas show NBER designated recessions.

Source: Bureau of Labor Statistics (2017), Series LNS14000000 and LNS13327709.

\section{Figure 6 US unemployment and underemployment as a percentage of the labour force}

(the involuntarily underemployed) has also fallen, from a peak of 17 per cent in 2010, but it still stood at just over 8 per cent in 2017. In addition, several million workers have simply disappeared from the official figures, presumably because they are unemployed but not entitled to any benefits, and so have no incentive to register. ${ }^{15}$

The depressing situation confronting many workers in the US has been reflected in a number of sobering studies. An investigation by Anne Case and Angus Deaton identified a sharp rise in deaths among non-elderly white US workers stemming largely from drug and alcohol poisoning (Case/Deaton 2015). Opiate abuse, located particularly in working-class communities, has become so serious that in October 2017 President Trump announced a national emergency, arguing that the opioid epidemic was the worst drug crisis in US history (Financial Times $2017 \mathrm{~d}$ ). ${ }^{16}$ The devastating conditions confronting some male workers was summarised by one study as follows:

Adverse shocks to local employment opportunities stemming from rising international competition from China in manufactured goods yield a fall in men's relative employment and earnings; an increase in the rate of male mortality from drug and alcohol abuse; a reduction in the net availability of marriage-age males in affected labor markets; a reduction in the fraction of young adults entering marriage; a fall in fertility accompanied by a weak rise in the fraction of births to teen and unmarried mothers; and a sharp jump in the fraction of children living in impoverished and single-headed households. (Autor et al. 2017: 36-37)

By 2017, total employment in the US had risen to 6 per cent above the previous peak in 2008. The strongest growth of jobs has been in health and education (19 per cent), leisure and hospitality (17 per cent) and professional and business services (15 per cent). In the case of manufacturing, although there has been a steady, if slow, rise since 2010, employment in 2017 was still 17 per cent below that in 2008 (and a full 28 per cent below the figure for 2000) (Bureau of Labour Statistics 2017). Despite the lower employment, however, manufacturing output had by 2017 returned to its 2008 level. This is partly explained by the return of some manufacturing jobs to the US. According to one report,

15. Bureau of Labor Statistics (2017), Series LNS14000025 (men), LNS14000026 (women), LNS13327709 (including involuntarily underemployed) and LNS11300000 (participation rate). 16. The Financial Times report also noted that, according to Alan Krueger of Princeton University, rising opioid prescriptions from 1999 to 2015 may account for about a fifth of the decline in men's labour force participation. 
the 'reshoring' of jobs from China and other countries has led to an increase of 400000 manufacturing jobs and another 1.2 million support jobs since 2010. The report argues that when the costs of shipping, inventories and other expenses are taken into account, it had become less costly to produce some goods in the US if that is where they would be consumed (Boston Consulting Group 2017).

Although employment has increased quite strongly, it has been associated with a hollowing out' of middle-income jobs. There has been a strong growth of low-wage jobs, and there has also been an increase in the number of upper-income, high-skilled jobs, but there has been a notable decline in the availability of the type of secure, middle-income jobs which provided many members of the US working class with an unprecedented standard of living in the decades after the Second World War (PEW Research Centre 2016). Many jobs have been automated and, in addition, companies have shifted their manufacturing activities to lower-wage countries (Economic Policy Institute 2017). Indeed, a part of Donald Trump's success in appealing to white, working-class voters has been in emphasising the loss of jobs due to supposedly 'unfair' competition from abroad. There has also been a marked deterioration in conditions for those workers who are employed in the US. According to a study by the University of California, 34 per cent of the families of workers directly involved in manufacturing production are enrolled in one or more public safety net programmes, while for those employed through staffing agencies the figure is 50 per cent (Jacobs et al. 2016: 3).

Although unions are one of the largest organised sets of institutions in the US, membership in the private sector has been steadily declining since the 1950s (Economic Policy Institute 2017). In 1980 only 20 per cent of private-sector workers were members of unions and by 2017 this had fallen to just 6.5 per cent. Membership fell sharply as a result of the most recent crisis; nevertheless, despite virulent opposition from many employers, the absolute number of members in the private sector increased by around half a million between 2010 and 2017, and many of the new members were younger workers under the age of 35 . In the public sector, by contrast, union membership actually increased in the 1970s, and from 1980 until 2009 it fluctuated around 37 per cent of employees, although this then fell slightly from 2010 to reach 35 per cent in 2017 (Hirsch/Macpherson 2017).

Since 2015 wages have begun to rise in real terms, but for many workers the increase has been quite limited. By 2017, median real earnings for men had merely recuperated the losses in the immediate aftermath of the crisis and, as shown in Figure 7, had scarcely risen above their level in the 1980s. For women the situation was somewhat better: by 2017 median

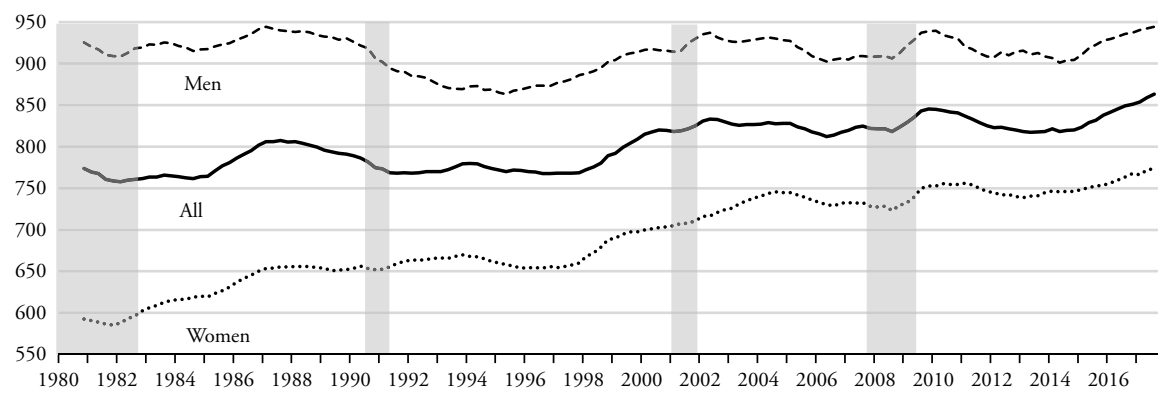

Note: Shaded areas show NBER designated recessions.

Source: Bureau of Labor Statistics (2017), Series LEU0252881600, LEU0252881600 and LEU0252882800. Four quarter moving average rebased from 1982-1984 average prices.

Figure 7 US median real weekly earnings, 2017 dollars 
earnings had risen some 3 per cent above their post-crisis peak, almost 10 per cent above their peak in 2000 and a full 30 per cent above their level in the early 1980s. A more detailed analysis available up to 2016 shows that lower incomes have evolved in a similar way to those at the median level, but higher-income groups have risen much more strongly (Economic Policy Institute 2016 and EPI Data Base). For men, real wages at the 90th percentile had increased by 12 per cent since 2000 while those at the 95 th percentile were up by 30 per cent. For women, those at the 90th percentile did even better than male workers, with a rise of 16 per cent since 2000, although those at the 95th percentile did less well than their male colleagues, with a rise of 23 per cent. At the 95th percentile, men earned $\$ 70$ an hour while women earned $\$ 50$, a gap of 29 per cent, and, whereas the gap had been falling, since 2007 it has widened again. For those at the very top - presumably predominantly men - incomes increased even more. According to the most recent figures from Piketty et al.'s World Wealth and Income Database (WID.world 2018), the share of the top 1 per cent in US incomes continued its steady rise from 10 per cent in 1980 to 18 per cent in 2000 and reached 20 per cent by 2014 , the latest year available. A more recent report claimed that the number of billionaires in the US had increased from 538 in 2015 to 563 in 2016, and that their combined wealth had risen from $\$ 2.2$ trillion to $\$ 2.4$ trillion (UBS/PwC 2017: 12).

The tax changes approved by Congress at the end of 2017 will result in a decline in tax payments for most - but not all - in the first year, although the longer-term benefits will accrue largely to those with top incomes. According to estimates by the mainstream Urban-Brookings Tax Policy Center, in 2018 taxpayers in the lowest quintile, with an average income of less than $\$ 25000$, will see a reduction of $\$ 60$ a year, or 0.4 per cent of after-tax income (Tax Policy Center 2017), as shown in Table 1. Taxpayers in the middle quintile, with incomes between $\$ 49000$ and $\$ 86000$, will receive tax cuts of about $\$ 900$, or 1.6 per cent of after-tax income. Taxpayers in the 95th to 99th percentiles, with incomes between $\$ 308000$ and $\$ 733000$, will obtain the largest share of the reductions, with average cuts of $\$ 13500$ or 4.1 per cent of after-tax incomes. Taxpayers in the top 1 per cent, with incomes above $\$ 733000$, will receive an average cut of $\$ 51000$, or 3.4 percent of after-tax income. In total, 65 per cent of the cuts will benefit the top 20 per cent, while 20 per cent of the cuts will accrue to the top 1 per cent. The magnitude of the cuts will decline slightly in the years up to 2025, but the cuts then automatically lapse. According to the Tax Policy Center, for most taxpayers this will make little difference, although for those in the top 1 per cent of incomes, there will be a further average reduction of some $\$ 21000$.

\section{CONCLUSION}

US economic growth since the 2007-2009 recession has been unusually low. As the expansion enters its ninth year, the weakening of profitability and investment, which have in the past served as leading indicators, suggests that the expansion could be approaching an end. Despite record earnings, corporate-sector debt has increased to an all-time high, largely due to the exceptionally large payouts to shareholders. The banking sector has been obliged to raise its capital reserves, although these still remain low, and the new banking rules, introduced in the aftermath of the crisis, are extraordinarily complex. The Trump government is proposing to relax the regulations, especially for smaller banks, but they remain highly complex. The shadow banking system, which contracted sharply in the aftermath of the crisis, has begun to expand again but it has not been subject to serious reform and is again taking increasing risks. Unemployment has fallen sharply since the recession, but wage growth has remained surprisingly subdued for all but top 


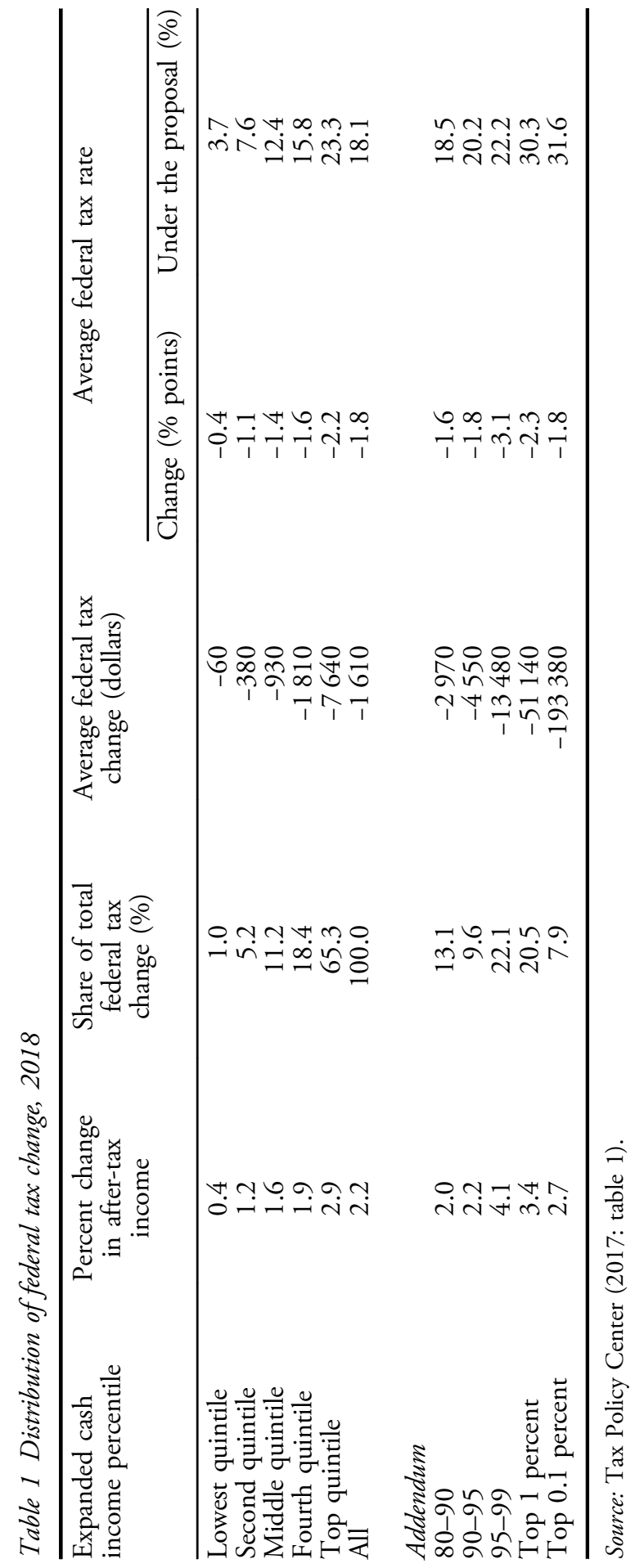


earners. While households have reduced their indebtedness through mortgages, consumer indebtedness has begun to rise.

After taking office, the Trump government immediately moved to relax a whole range of regulations which had sought to tame business's wilder behaviour and to protect the interests of consumers. Its first major legislative initiative, the reform of the Affordable Care Act, initially failed to gain sufficient Congressional support, but a subsequent executive order and, especially, provisions attached to the signature tax reform law, are intended to undermine the universal coverage that had been introduced by the Obama government. Some commentators have searched for a coherent strategy in Trump's policies. The major tax law agreed at the end of the first year is projected to provide greatest benefit to industries which are primarily based in the US, while the cuts in personal taxes will overwhelmingly benefit the top 20 per cent, who gain 60 per cent of the total reduction. At the end of the first year in office, far from any coherent plan to revitalise the economy, Trump appears to have used his position as president to promote an unparalleled plundering of the US economy's resources in favour of some of the very wealthiest sections of US society.

\section{REFERENCES}

Adamati, A., Hellwig, M. (2014): The Bankers' New Clothes: What's Wrong with Banking and What to Do about it, Princeton, NJ: Princeton University Press.

Autor, D., Corn, D., Hanson, G. (2017): When work disappears: manufacturing decline and the falling marriage-market value of men, NBER Working Paper, No 23173, Cambridge, MA.

BEA (Bureau of Economic Analysis) (2017a): National Income and Product Accounts, Washington, DC: Bureau of Economic Analysis.

BEA (Bureau of Economic Analysis) (2017b): International Transactions, Washington, DC: Bureau of Economic Analysis.

Bivens, J. (2017): A 'high-pressure economy' can help boost productivity and provide even more 'room to run' for the recovery, Report, Economic Policy Institute, Washington, DC, March.

Blinder, A. (2013): After the Music Stopped: The Financial Crisis, the Responses, and the Work Ahead, New York: Penguin Press.

Boston Consulting Group (2017): Honing US manufacturing's competitive edge, January, URL: www.bcg.perspectives.com (accessed 6 January 2018).

Bureau of Labor Statistics (2017): Series LNS 11300000, LNS13327709, LNS14000000, LNS14000025, LNS 14000026, Washington, DC: Bureau of Labor Statistics.

Case, A., Deaton, A. (2015): Rising Morbidity and Mortality among White, Non-Hispanic Americans in the 21st Century, Proceedings of the National Academy of Sciences, (49), 15078-15083, URL: http://www.pnas.org/content/pnas/112/49/15078.full.pdf.

Cetorelli, N., Mandel, B., Mollineaux, L. (2014): The Evolution of Bank Complexity, in: FRBNY Economic Policy Review, December, 85-106.

Cogan, J.F., Hubbard, G., Taylor, J.B., Warsh, K. (2017): On the prospects for higher economic growth, URL: www.hoover.org (accessed 7 January 2018).

Conference Board, The (2017): Total Economy Database, Groningen, December.

Duménil, G., Lévy, D. (2013): The Crisis of Neoliberalism, Cambridge, MA: Harvard University Press.

Economic Policy Institute (2016): The state of American wages, Report, Washington, DC, March.

Economic Policy Institute (2017): Adding insult to injury: how bad policy decisions have amplified globalization's cost for American workers, Report, Washington, DC, July.

Eisinger, J. (2017): The Chickenshit Club: Why the Justice Department Fails to Prosecute Executives, New York: Simon \& Schuster.

Evans, T. (2009): The 2002-2007 US economic expansion and the limits of finance-led capitalism, in: Studies in Political Economy, 83(May), 33-59. 
Federal Reserve Bank of New York (2017): Quarterly trends for consolidated U.S. banking organizations, Q2, Quarterly report, New York.

Federal Reserve Board (2014): Federal Reserve approves final rule to help ensure banks maintain strong capital provisions, Press release, Washington, DC, June.

Federal Reserve Board (2017): Financial accounts of the United States, Washington, DC.

Financial Stability Board (2017): List of global systemically important banks (G-SIBs), URL: http:// www.fsb.org/wp-content/uploads/P211117-1.pdf (accessed 7 January 2018).

Financial Times (2017a): Banks rack up $\$ 150 \mathrm{bn}$ in US fines since start of the financial crisis, in: Financial Times, 7 July.

Financial Times (2017b): On life support, in: Financial Times, 11 August.

Financial Times (2017c): US investors should be wary of over-valued stocks, in: Financial Times, 16 August.

Financial Times (2017d): US opioid crisis holds back jobs market recovery, says study, in: Financial Times, 5 September.

Financial Times (2017e): A policy bent out of shape, in: Financial Times, 2 October.

Financial Times (2017f): Trump signs order to begin diluting Obama care, in: Financial Times, 10 October.

Financial Times (2017g): Bank rules are tough enough, argues Trump nominee for Fed chair, in: Financial Times, 29 November.

Financial Times (2017h): Trump's next trade target, in: Financial Times, 7 December.

Financial Times (2017i): US companies set for big windfall from tax overhaul, in: Financial Times, 18 December.

Financial Times (2017j): Finance groups face $\$ 50$ billion tax hit, in: Financial Times, 18 December.

Financial Times (2017k): Doubts raised over long-term benefits of US tax shake-up, in: Financial Times, 22 December.

Financial Times (2017l): Selling the tax deal, in: Financial Times, 23 December.

Flatness, A., Rasmussen, C. (2017): U.S.-produced value in U.S. imports from NAFTA, Government report, Office of Trade and Economic Analysis, Department of Commerce, Washington, DC, 22 September.

Foroohar, R. (2016): Makers and Takers: The Rise of Finance and the Fall of American Business, New York: Crown Business.

Gordon, R.J. (2016): The Rise and Fall of American Growth, Princeton, NJ: Princeton University Press.

Gutiérrezy, G., Philipponz, T. (2017): Investment-less growth: an empirical investigation, September, NBER Working Paper, No 22897, Cambridge, MA.

Hirsch, B.T., Macpherson, D.A. (2017): Union membership and coverage database from the CPS, URL: Unionstats.com.

International Federation of Robotics (2017): Industrial robots, URL: https://ifr.org.downloads (accessed 5 January 2018).

Jacobs, K., Perla, Z., Perry, I., Graham-Squire, D. (2016): Producing poverty: the public cost of low-wage production jobs in manufacturing, Report, Berkeley Center for Labor Research and Education, University of California, May.

Joint Committee on Taxation (2017): Macroeconomic analysis of the 'Tax cuts and jobs Act', Washington, DC, 16 November.

Lazonick, W. (2015): Stock buybacks: from retain-and-reinvest to downsize-and-distribute, Report, Centre for Effective Public Management at Brookings, April.

McKinsey Global Institute (2017): Making it in America: revitalizing US manufacturing, Report, November, URL: www.mckinsey.com (accessed 5 January 2018).

Milberg, W., Winkler, D. (2013): Outsourcing Economics: Global Value Chains in Capitalist Development, Cambridge, UK: Cambridge University Press.

Neiwert, D. (2017): Alt-America: The Rise of the Radical Right in the Age of Trump, London and New York: Verso.

New York Times, The (2017a): Trump's 'great infrastructure program'? stalled, in: The New York Times, 24 July. 
New York Times, The (2017b): After Trump hedges his condemnation of hate, C.E.O.s organize a mass defection, in: The New York Times, 17 August.

New York Times, The (2017c): Senate Republicans say they will not vote on health bill, in: The New York Times, 27 September.

New York Times, The (2017d): Consumer bureau's new leader steers a sudden reversal, in: The New York Times, 6 December.

New York Times, The (2017e): A historic tax heist, in: The New York Times, 2 December.

New York Times, The (2017f): Heading toward tax victory, Republicans eye next step: cut spending, in: The New York Times, 3 December.

New York Times, The (2017g): What's in the final Republican tax bill, in: The New York Times, 16 December.

New York Times, The (2018), Trump's infrastructure plan puts burden on state and private money, in: The New York Times, 13 February.

Office of Financial Research (2016): 2016 Annual Report to Congress, Washington, DC, December.

Passmore, W., von Hafften, A.H. (2017): Are Basel's capital surcharges for global systemically important banks too small? FEDS Notes, Board of Governors of the Federal Reserve System, Washington, DC, February.

Penn Wharton Budget Model (2017): The Senate tax cuts and job act, Macroeconomic model, University of Pennsylvania, Philadelphia, 11 December.

PEW Research Centre (2016): America's shrinking middle class: a close look at changes in metropolitan areas, Washington, DC, May.

Pozsar, Z., Adrian, T., Ashcroft, A., Boesky, H. (2012): Shadow banking, FRBNY Staff Report No 458, Washington, DC, February.

Pozsar, Z., Adrian, T., Ashcroft, A., Boesky, H. (2013): Shadow banking, in: Economic Policy Review, 19(2), 1-16.

Roberts, M. (2016): The Long Depression: Marxism and the Global Crisis of Capitalism, Chicago: Haymarket.

Shiller Price-Earnings Index (2018), URL: www.econ.yale.edu/ shiller/data/ie_data.xls (accessed 6 January 2018).

Smith, J. (2016): Imperialism in the Twenty-First Century, New York: Monthly Review Press.

Tax Policy Center (2017): Distributional analysis of the conference agreement for the Tax Cuts and Jobs Act, Report, Urban Institute - Brookings Institution, Washington, DC, 18 December.

Taylor, J. (2017): 'Sound monetary policy', Testimony before the Subcommittee on Monetary Policy and Trade, Committee on Financial Services, US House of Representatives, Washington, DC, 16 March.

UBS/PwC (2017): Billionaires report 2017, URL: https://pwc.to/bl2017.

US Department of the Treasury (2017): A financial system that creates economic opportunities: banks and credit unions, Report, Washington, DC, June.

Wall Street Journal, The (2016): Fed vice chairman Stanley Fischer: 'great fear' about antiglobalization, in: The Wall Street Journal, 7 October.

White House, The (2018), Legislative outline for rebuilding infrastructure in America, Washington, DC, February.

WID.world (2018): Wealth and Income Database, URL: wid.world (accessed 7 January 2018). 